БАЛЧУГОВ Аркадий Владимирович - аспирант кафедры теории политики и коммуникации Нижегородского государственного университета им. Н.И. Лобачевского (603950, Россия, г. Нижний Новгород, ул. Ульянова, 2; islam-imоті@yandex.ru)

БЕЛЯНЦЕВ Алексей Евгеньевич - кандидат физико-математических наук, доцент кафедры прикладного политического анализа и моделирования Нижегородского государственного университета им. Н.И. Лобачевского (603950, Россия, г. Нижний Новгород, ул. Ульянова, 2; islam-belkinn@ rambler.ru)

БУГРОВ Роман Владимирович - кандидат политическихнаук, доцент кафедрымировой дипломатии и международного права Нижегородского государственного университета им. Н.И. Лобачевского (603950, Россия, г. Нижний Новгород, ул. Ульянова, 2; bougrov@таil.ru)

НЕМЦОВА Ольга Анатольевна - кандидат психологических наук, доцент кафедры английского языка для гуманитарных специальностей Нижегородского государственного университета им. Н.И. Лобачевского (603950, Россия, г. Нижний Новгород, ул. Большая Покровская, 37; nemtsovao@inbox.ru)

\title{
«НОВЫЕ МЕДИА» В СОВРЕМЕННОЙ РОССИЙСКОЙ ПОЛИТИКЕ: ПРЕИМУЩЕСТВА И ПОТЕНЦИАЛ
}

Аннотация. В статье анализируются вопросы, связанные с политизированной блогосферой в современной России. Авторы выявляют плюсы «новых медиа» в сравнении с традиционными СМИ, определяют большой потенциал блогов в развитии политических идеологий.

Ключевые слова: блог, политика, влияние, агитация, преимущества, идеология

$\mathrm{B}_{\mathrm{r}}^{\mathrm{H}}$ настоящее время традиционные СМИ утрачивают не только свое влияние, но даже значение ввиду того, что в цифровую эру активно развиваются «новые медиа» [Грошев, Титиева, Устинкин 2004: 26]. Яркий пример тому: одно из наиболее известных нижегородских региональных изданий - газета «Нижегородский рабочий», - по сути, прекращает свое существование ${ }^{1}$. Не может похвастаться высоким рейтингом и, например, региональный телеканал ННТВ. При этом самый топовый нижегородский блогер Полина Зиновьева имеет более миллиона подписчиков ${ }^{2}$, т.е. число людей, по тем или иным причинам интересующихся ее жизнью и мнением по какому-либо вопросу, вполне сопоставимо с населением Нижнего Новгорода. Можно, разумеется, говорить о том, что «новые медиа» существенно уступают традиционным СМИ в качестве журналистики, что уровень самоцензуры в них значительно ниже [Калакина и др. 2018: 182], однако факт остается фактом: «новые медиа» активно наступают и начинают побеждать традиционные.

В этих условиях выглядит естественным и использование «новых медиа» в политической сфере. Началось это, как справедливо отмечал Е.П. Чекулаев, еще в нулевых годах [Чекулаев 2010], однако по-настоящему расцвет политизированного блогинга в России начался уже в настоящее десятилетие. Сегодня блогинг используется в политических целях как политическими деятелями

1 Новый собственник закрывает газету «Нижегородский рабочий». Доступ: https://newsnn.ru/ news/politics/03-10-2018/novyy-sobstvennik-zakryvaet-gazetu-nizhegorodskiy-rabochiy-smi (проверено 14.12.2018).

2 Канал Полины Зиновьевой. Доступ: https://www.youtube.com/channel/UCjNXgpc8kT2c7RhyB3aoFcA (проверено 14.12.2018); Страница Полины Зиновьевой в Instagram. Доступ: https://www.instagram.com/ polly_zinovieva/ (проверено 14.12.2018). 
разного уровня [Магера 2016; Халиуллина 2017; Щекина 2015], так и, что совершенно естественно, активистами с самыми разными убеждениями. То есть, политизированные блоги стали важным средством борьбы за умы населения и голоса избирателей [Дамианов 2018; Кренвальк 2016]. Периодически появляется рейтинг отечественных политических блогеров ${ }^{1}$.

По нашему мнению, прежде всего важно отметить два основных аспекта бурного развития политизированного сегмента российской блогосферы. Первый из них связан с тем, что блоги стали незаменимыми в борьбе за электорат. При этом нельзя не упомянуть, что ведение блога является куда как менее затратным, нежели содержание традиционного СМИ. Кроме того, нельзя не признать, что блогеры могут писать свои посты, выкладывать клипы и т.п., основываясь на собственных убеждениях, а не по причине ангажированности. Итак, традиционное СМИ по определению дороже блога (отдельные исключения скорее подтверждают этот тезис, нежели его опровергают), но его охват может быть меньшим, причем даже значительно [Рейсбих 2014: 156; Фомин, Акаев 2009: 85]. То есть, если рассматривать эффективность как отношение затрат к результату (в данном случае - к количественным характеристикам аудитории), то преимущество блогов очевидно.

Второй крайне значимый момент связан с тем, что именно в блогах в настоящее время идут активные политические дискуссии, объективно содействующие развитию идейных доктрин. В этой связи подчеркнем, что слухи о кончине ЖЖ 2 выглядят, по меткому высказыванию М. Твена, «слегка преувеличенными». Скорее можно говорить о том, что Россия, к сожалению, не является сейчас самой читающей страной в мире, в связи с чем далеко не все, в т.ч. и имеющие интерес к политике, в состоянии читать тексты политического характера. Но читающая публика испытывает интерес к слову, а потому остается верной ЖЖ, на платформе которого и идут жаркие идеологические дебаты. Число комментариев в ЖЖ топовых блогеров дает возможность говорить об этом с полной уверенностью.

Можно привести небезынтересный пример. Сравнительно недавно довольно бурную дискуссию в виртуальном пространстве вызвал пост блогера Дениса Грачева (кстати, не самого топового!) «Исповедь самозанятого» ${ }^{3}$. В целом его текст, обличающий современное российское государство за крайне неэффективное расходование бюджета и содержащий идеи о желательности неуплаты налогов, может быть охарактеризован как либертарианский [Пахомова, Сальников, Фомичев 2018: 44]. При этом мало кто из политически активных россиян может вспомнить программный текст или какое иное публичное выступление за последние несколько лет кого-либо из лидеров трех парламентских фракций, т.е. Г.А. Зюганова, В.В. Жириновского и С.М. Миронова, которое бы активно обсуждалось в обществе. А ведь по идее как минимум первому и второму из них есть что сказать гражданам, ибо, помимо богатого политического опыта, они еще и обладают ученой степенью доктора философских наук и написали немало работ (особенно В.В. Жириновский, написавший в прошлом 20 книг). Впрочем, если и запомнился он в последние годы, то только парой скандалов, но отнюдь не на ниве идеологии.

\footnotetext{
1 Рейтинг политических блогеров России. Доступ: https://yablor.ru/blogs/reyting-politicheskihblogerov-ross/3044551; https://yablor.ru/blogs/reyting-politicheskih-blogerov-ross/3044551 (проверено 14.12.2018).

2 Блогеры идут в политику. Доступ: http://actualcomment.ru/blogery-idut-v-politiku-1704281119.html (проверено 14.01.2018).

3 Денис Грачев. Исповедь самозанятого. Должны ли граждане платить налоги государству, которое ничего им не должно? Доступ: https://kukmor.livejournal.com/2442758.html (проверено 20.12.2018).
} 
Таким образом, политизированный блогинг в России обладает большим агитационным и идеологическим потенциалом. Укажем также, что если первый из них уже довольно неплохо изучен, то второй - пока еще нет. При этом появления новых идеологов, овладевающих умами россиян, можно ожидать прежде всего именно в виртуальном пространстве, особенно в ЖЖ.

\section{Список литературы}

Грошев М.М., Титиева Т.М., Устинкин С.В. 2004. Информационное общество в России: проблемы и перспективы: учебное пособие. Н. Новгород: Изд-во НГЛУ им. Н.А. Добролюбова. 208 с.

Дамианов Д.Ю. 2018. Информационные технологии и их применение в современном политическом пространстве - Постулат. № 5. Доступ: http://epostulat.ru/index.php/Postulat/article/view/1468 (проверено 20.04.2019).

Калакина К.А., Насонов Д.С., Пахомова Е.А., Фоменков А.А. 2018. Новые медиа и новые опасности: О российском политизированном блоггинге. Культура, образование и искусство: партнерство семьи и дополнительного образования в формировании профессиональных иенностей: сборник статей по материалам всероссийской научно-практической конференции ученых-исследователей, специалистов; преподавателей вузов, колледжей, школ, учреждений дополнительного образования; руководителей образовательных учреждений; аспирантов, студентов. Н. Новгород: НГПУ им. Козьмы Минина. С. 181184.

Кренвальк А.А. 2016. Политические блоги как средство политического воздействия. - Вопросы политологии. № 2(22). С. 75-81.

Магера А.О. 2016. Социальные сети и блоги политиков Псковского региона как инструмент политического воздействия на умы потенциальных избирателей. - Гуманитарные научные исследования. № 6(58). С. 199-202.

Пахомова Е.А., Сальников М.В., Фомичев М.Н. 2018. Слабости современной российской либертарианской правовой концепции. - Правовое государство: теория и практика. Т. 1. № 51. С. 43-48.

Рейсбих С.А. 2014. Блог как инструмент политической борьбы. - Политические институты и процессы. № 2. С. 154-157.

Фомин О.Н., Акаев Д.В. 2009. Политический блог: Опыт социологического анализа. - Среднерусский вестник общественных наук. № 3(12). С. 83-87.

Халиуллина М.С. 2017. Блог как средство коммуникации региональных политических деятелей с электоратом. - Вопросы теории и практики жсурналистики. T. 6. № 4. С. 603-614.

Чекулаев Е.П. 2010. Роль «прямых линий» и интернет-блога в информационной политике РФ в 2000-е годы. - Вестник Московского государственного областного университета. Сер. История и политические науки. № 3. С. 147149.

Щекина И.А. 2015. Блоги губернаторов: Коммуникативные возможности и имиджевые риски. - Вестник Воронежсккого государственного университета. Сер. Филология. Журналистика. № 3. С. 174-177. 
BALCHUGOV Arkadiy Vladimirovich, postgraduate student at the Chair of Theory of Politics and Communication, Lobachevsky State University of Nizhny Novgorod (2 Ul'yanova St, Nizhny Novgorod, Russia, 603950; islam-imomi@ yandex.ru)

BELYANTSEV Aleksei Evgen'evich, Cand.Sci. (Phys. and Math. Sci.), Associate Professor of the Chair of Applied Political Analysis and Modeling, Lobachevsky State University of Nizhny Novgorod (2 Ul'yanova St, Nizhny Novgorod, Russia, 603950; belkinn@rambler.ru)

BUGROV Roman Vladimirovich, Cand.Sci. (Pol.Sci.), Associate Professor of the Chair of World Diplomacy and International Law, Lobachevsky State University of Nizhny Novgorod (2 Ul'yanova St, Nizhny Novgorod, Russia, 603950; bougrov@mail.ru)

NEMTSOVA Olga Anatol'evna, Cand.Sci. (Psych.), Associate Professor of the Chair of English Language for Humanities, Lobachevsky State University of Nizhny Novgorod (37 Bol'shaya Pokrovskaya St, Nizhny Novgorod, Russia, 603950; nemtsovao@inbox.ru).

\section{NEW MEDIA IN THE CONTEMPORARY RUSSIAN POLITICS: ADVANTAGES AND POTENTIAL}

Abstract. This article analyzes issues related to the politicized blogosphere in modern Russia. The authors reveal advantages of new media in comparison with traditional ones and define the great potential of blogs in the development of political ideologies.

Keywords: blog, politics, influence, agitation, advantages, ideology

УДК 32.019.51

ЗЛОБИН Максим Александрович - аспирант Нижегородского государственного лингвистического университета им. Н.А. Добролюбова (603155, Россия, г. Нижний Новгород, ул. Минина, 31 А; zlobinmaxim@yandex.ru)

\section{ТЕХНОЛОГИИ ФОРМИРОВАНИЯ ПОЛИТИЧЕСКОГО ДИСКУРСА В УСЛОВИЯХ СЕТЕВОГО ОБЩЕСТВА}

Аннотация. В статье рассматриваются основные этапы и особенности возникновения в России сетевого общества, связь этого процесса с развитием телекоммуникационных технологий и российского сегмента Интернета. Автор дает краткую характеристику наиболее типичных способов и приемов политизации контента в сети Интернет, в особенности с манипулятивными целями, и подчеркивает, что общение и дискуссии на актуальные темы внутри сетевых сообществ и соцсетей в подавляющем большинстве случаев политизируется, в т.ч. искусственно, способствуя формированию и развитию политического дискурса. Среди основных способов формирования политического дискурса автор выделяет воздействие на участников коммуникации, на ее тематику и контекст и делает вывод о необходимости подробного изучения технологий формирования политического дискурса, в Т.ч. в интересах национальной безопасности.

Ключевые слова: политический дискурс, сетевое общество, сетевая коммуникация, социальные сети, оппозиция, Интернет, национальная безопасность

$\mathrm{B}$ настоящее время глобализация экономических процессов и растущая роль информационных технологий, позволяющие некоторым исследователям говорить о начавшемся (а по мнению отдельных из них, уже завершившемся) 